\title{
The Importance of Theology, Especially Theological Ethics, within Higher Education in the Field of Social Work Study Jindřich Šrajer
}

\begin{abstract}
This paper reflects the importance of theology studies and theological ethics in higher education in the field of social work. The article clarifies the essence of theology and theological ethics in their substantiality and transformation. It particularly emphasises the post-conciliar form of these sciences, especially theological ethics and its accents. These include the emphasis on personal responsibility (conditioned by the ability to distinguish and to make a decision, that is, to acquire wisdom and providence). In these accents (besides other benefits, e.g., a complex view of reality) one can see the current importance of theology studies, respectively the importance of theological ethics in higher education (specifically for social work and the quality of its practice).
\end{abstract}

Keywords: theological ethics, social work, social worker, theology, education, personal responsibility, natural law, Christianity

Looking at the minimum standards of social work studies compiled by the Association of Educators in Social Work, we find that their integral part is philosophy and ethics - they are even mentioned in the first place - but there is no mention of theology, respectively of theological ethics. In the Ministry of Education, Youth and Sports documents (for the area of education in social work), we find only a note stating that in the 1990s when the study of social work was newly conceived in the Czech environment, those studies were done in the form of so-called supplementary studies to the basic programme of the universities. Studies in social work were combined with psychology, sociology, pedagogy, economics, law, health, and also theology. Even today, it is noted in the documents mentioned that

The current content of the university studies of social work continues to be largely shaped by the fact that it is created at workplaces with different fields of study and with a primary orientation on sociology, pedagogy, theology, etc. ${ }^{1}$

1 Petr ČERNIKOVSKÝ, Jiří HNILICA and Eva PASÁČKOVÁ (eds), Národní kvalifikační rámec terciárního vzdělávání České republiky, MŠMT, 2. díl. Oblasti vzdělávání, Praha: Tauris, 2012, p. 130. 
This fact itself raises questions and it is undoubtedly appropriate to answer them adequately. For us, the crucial issue is the importance of the role of theology, respectively the role of theological ethics when studying social work. Is it possible to perceive theology, or theological ethics (as part of a social work studies framework which has a distinctly interdisciplinary character) as a discipline beyond such a framework, as an imaginary icing on a cake that may or may not be there? Or does it have an important or perhaps even exclusive position within those studies and the practice of social work, given the theoretical and methodological foundations of social work which predestine its quality?

The question of higher education in theology is not only a relevant issue in the study of social work but also in university education in general. Not surprisingly, in 2006, Harvard University, one of the oldest universities in the US, established a commission in order to reform the compulsory general education base at the University. This commission has identified the relationship of faith and reason as one of the central subjects of university education. In this education process, it should not be about embedding a specific religious attitude in students but to help them understand the relationship between religious and secular institutions, thoughts, and forms of practice. Students should learn more precisely to understand their own beliefs and values. It should, among other things, help them to become more educated and therefore more competent. ${ }^{2}$

The abovementioned general aims of studying the relationship of faith and reason (respectively theology), which justify its importance in university education due to the requirement of comprehensive education of students, can be transferred without reservation to the area of education in social work. This is emphasised by the words of Joseph Ratzinger, later Pope Benedict XVI (200513). In the diagnosis of the moral problems of the times, he points, among other things, to a new inclination to morality and religion (respectively to the need to revitalise the motivation to serve suffering people), and emphasises that no matter how important the professional qualification for this service is (in our case, social work), without a deep moral and religious basis it remains merely a technique and does not do what is humanly decisive. ${ }^{3}$

What are the humanly decisive factors in social work that can be found in reference to the basic value framework of social work, respectively in reference to the identified educational objectives in this area? These include: the emphasis on protecting and promoting human dignity, human rights, and social justice, as well as the application of critical thinking; understanding the situation of the client and/or groups in their overall life context (respectively in the overall social context); increasing the competence of clients leading to a qualitative change in their lives; improving the conditions for the graduate's own professional and personal development, especially with regard to working with clients in difficult life situations, etc. ${ }^{4}$ These basic definitions or requirements, however, assume value content and motivational incentives. Without that, they remain less effective, because they are often very poorly understandable and unachievable for involved ones. Theology, respectively theological ethics, works with these contents and incentives a priori, trying to understand them. However, this discipline is not protected against the risks and challenges that can confront it over time in the framework of a presented paradigm.

In an effort to fulfil the purpose of this treatise - to point out the importance of theology, respectively theological ethics, as part of the study of social work - first, we try briefly to characterise the reality, a kind of foothills in the layout of social work. Without that, it is impossible to fully

2 Cf. ( ) RC MONITOR, USA: Teologie patří k základu univerzitního vzdělání, 19th October 2006 (on-line), see: https://www.rcmonitor. cz/download/2006-16.pdf, p. 3.

3 Joseph kardinál RATZINGER, Naděje pro Evropu? Církev a svět. stav - diagnózy - prognózy, Praha: Scriptum, 1993, p. 17.

4 See ČERNIKOVSKÝ, HNILICA and PASÁČKOVÁ (eds.), Národní..., pp. 132-133. 
understand the actuality of concrete needs and challenges when talking about the study and practice of social work and thus the significance of theology, respectively theological ethics in them. In particular, we will focus on the absence or weakening of individual ethical motivations based on the analysis offered by the theologian Joseph Ratzinger. This includes, among other things, the requirement to clarify the theology, respectively theological ethics, its dynamics and transformations, which can and want to be a response to the demands of the present time and specific areas of human practice, in our case to the demands of social work.

\section{The Absence or Weakening of Individual Ethical Motivation}

The fundamental question of theological ethics in its post-conciliar form (which reflects the newly discovered responsive structure of the biblical ethos) is the question of the importance and level of individual ethical motivations, of their stimulation. This also assumes the reflection of the real level of this motivation, as to how much we can capture it.

The theologian Ratzinger speaks about the current moral boom, a newly seen attachment towards morality and religion. However, like the philosopher and sociologist Gilles Lipovetsky, they do not neglect the reality of a real weakening of individual ethical motivation. Both agree that moral values have lost their prominence (thanks to technology, and respectively thanks to a society determined by consumption) and hence their claimed component. They note that there is no commitment to moral values that become binding for man even when those have negative consequences for him or her (when his or her personal freedom and his or her own peace are at risk). The decisive factor here, according to them, is not reason and will, but just feeling. Ratzinger attributes this to the understanding of religion as a mere enhancement of emotion, respectively the non-acceptance of religion as the order of reason and will, and its binding moral forces (that bind both the community and the individual). ${ }^{5}$

Ratzinger adds that only a small number of people in modern society believe in the existence of God's commandments and even less believe that those are unmistakably mediated by the Church, and the religious community, and that our being becomes true in the harmony of our will and God's will. At the same time, he reminds us that since ancient times, there has been a 'fundamental feature of human life, something inherent to all cultures, that is, the teaching of the objective values that emerge in the world and its being. Human beings are subject to duties, morals, and there are attitudes in accordance with the human nature, and attitudes that contradict it. In other words, Ratzinger recalls, all the great cultures have a common basic intuition regarding the moral character of being itself and the necessary harmony of the human being with the message of nature, and that these are therefore both common and great moral imperatives. ${ }^{6}$

According to Ratzinger, the contemporary moral problem is that we have separated ourselves from the abovementioned prehistoric obvious understanding, from that basic common intuition. As a result of natural science thinking, the gap between the world of feelings and the world of reality is being created. Morality and religion have no place in the objective world; they fall into a subjective sphere. Man is objectivised in the mechanical evolutionary process of the world, thereby deprived of his or her essence. In other words, according to Ratzinger, the world is reduced to just reality and reason narrowed and being seen as the perception of quantity. What is inherent to humans is pushed into the subjective sphere and deprived of reality. It is denied here that practical 
reason is the real reason, the holder of moral cognition. It is seen only as an expression of subjective feelings without cognitive value. ${ }^{7}$ According to Ratzinger, our challenge is to learn to re-understand that the great moral knowledge of mankind is just as reasonable and as true as experimental knowledge from the field of natural and technical sciences. They are more true because they go deeper into the core of being and contribute more decisively to the humanness of man. ${ }^{8}$

The fundamental thing that Ratzinger wants to say with his analysis of the moral problem of the present era is that practical (or moral) reason is reason in the highest sense, because it penetrates deeper into the actual secret of reality than the experimental sense. ${ }^{9}$

At the same time, even if practical reason needs an experimental guarantee, it has to be stronger than what can be done in laboratories: it needs an experiment of undergone humanity, and this can only happen thanks to the experience of history. That is why practical reason has always been placed in a great interrelation of the experience and verification of complex ethical-religious visions. ${ }^{10}$

The decisive role in this 'experiment' is (according to Ratzinger) attributed to Christian faith, respectively to its moral vision, which is nothing specifically Christian, but 'a synthesis of the great intuition of mankind, ${ }^{11}$ and as such does not represent a restriction or paralysis of reason, but its full development. In its essence, it represents the guardian of moral duty, which is the very content of human dignity and human freedom. ${ }^{12}$

In principle, the abovementioned considerations indirectly go back to the question of the justness of studying the relationship of reason and faith, that is, theology or even social work within university studies. Among other things, it is about the fact that theology can unmask the dangerous tendencies of reducing man to the level of a machine (degrading and seeing him or her as a thing and trying to eliminate or dehumanise him or her), and can discover his or her full value. Theology mediates transcendence to man, the need for ethos (with the objectivity of duty and ultimate responsibility), and belief in creation (in the meaningfulness of being and its immortality). It reminds us that morality is not a matter of calculus, computation, or subjective whim; it is not something that is invented. It is found in a continuous process of discovery, development, and purification of knowledge. Even if we give to Christian theology the necessary exclusivity at this level, this does not exclude the constant requirement for the deepening and purification of its knowledge, respectively there being a duty 'which is natural to it and values shaping the mind of man which need to be newly formulated and justified.13

\section{The Nature of Theology}

From the point of view of the aforementioned and overall intent of our discourse, it is relevant at this point, at least in rough terms, to point out also the essence of theology, its assumptions, and its present form.

The fundamental, historically dogmatic problem of theology is the abovementioned relationship of faith and reason. The components of that relationship are also prerequisites for theology.

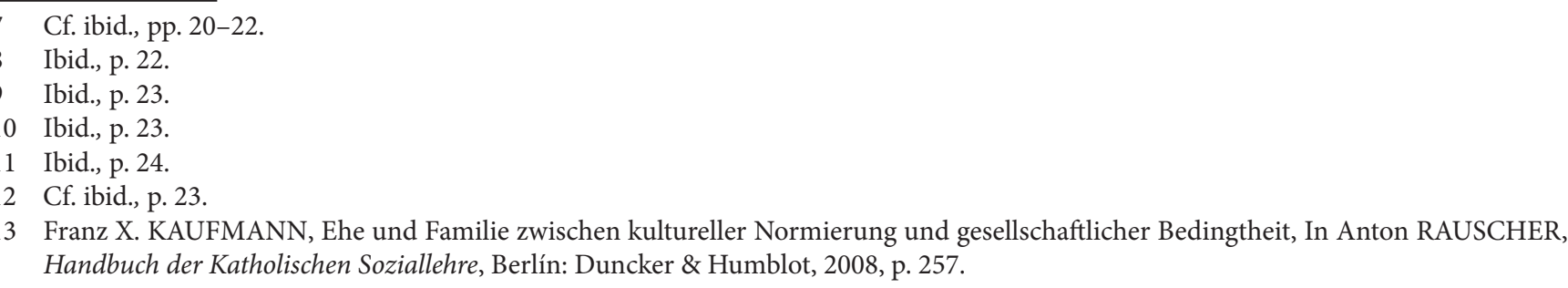


Theology 'is, in its essence, the believer's explicit, diligent listening to the inherent historical (realised) revelation of the Word of God, a scientific methodical effort which helps to know God, and a reflexive development of this subject of knowledge. ${ }^{14}$

Theology thus expects man to be a rational being capable of knowledge, reflection, speech, and to be the revealed Word of God. In seeking to know the basis of all reality, theology relies not only on reason, but also on a certainty which goes above reason (revelation).

Theology is, by its nature, a serving discipline. It listens carefully to the Word of God presenting it as a saving word for man. It cannot remain only with theoretical, abstract knowledge without proper participation in the life of man. It cannot be an 'existentially non-participating science'. ${ }^{15}$ Otherwise, its knowledge becomes fruitless and meaningless. In other words, when talking about the word of God (which as a judgment and redemption affects the whole human being) and theology (which is bound by its character), there is no other way for it than to reflect the life of man and related questions, including the possibilities and limitations of human knowledge of the facts of faith and their understanding. The task of theology is to listen to and try to understand the historical experience of man, and his or her possibilities of understanding his or her own life in the light of God's Word. In connection with faith and the Church, theology has a meditative and a kerygmatic function in this respect. As part of the Church, it has also a critical role to play in the Church and in the Church's life in faith. ${ }^{16}$

The present form of theology (which was formed in the first half of the 20th century and resonated in the statements of the Second Vatican Council and evolved immediately after it) is characterised by a historical and biblically oriented way of theological reflection, by a new reflection of history with the reinforcement of the meaning of anthropology and the knowledge of exact sciences. It leaves an abstract reflective deductive method of 'clearly defined and purely objective facts and content. ${ }^{17}$ It rather uses the inductive method, the form of 'essential statements' which, based on different historical expressions and forms and abstract reflection, open themselves to a phenomenologically and ontologically documented perspective. ${ }^{18}$

\section{The Nature of Theological Ethics and its Importance in Social Work}

A brief explanation of the nature of theology, its assumptions, and its present form allows us to go to a presentation of theological ethics, which is an integral part of it, and try to clarify the importance of this ethics in the study and practice of social work.

The present form of theology, which represents a breakaway from the almost legal and legitimate character of neo-scholastic fundamental theology and dogmatics (which in effect have sealed moral theology into rigid legal and casuistic thinking), ${ }^{19}$ gives the theological ethic the opportunity to re-develop. Officially, the Vatican Council in Optatam totius invited it to improve itself. In its scientific knowledge, moral theology should feed itself more richly with the teachings of Bible, and to illuminate the nobility of believers' vocations in Christ and their duty to bring benefit to

14 Karl RAHNER, Teologie, In Karl RAHNER and Herbert VORGRIMLER, Teologický slovník, Praha: Zvon, 1996, p. 349.

15 Ibid., p. 350.

16 Cf. RAHNER, Teologie, pp. 350-351.

17 Peter HÜNERMANN, Gaudium et spes včera a dnes: Kontrastní aktualizace znamení času neboli situace člověka v dnešním světě, in Jindřich ŠRAJER, Lucie KOLÁŘOVÂ, Gaudium et spes padesát let poté, Brno: CDK, 2015, p. 103.

18 Cf. HÜNERMANN, Gaudium et spes včera a dnes, p. 103.

19 Cf. ibid. 
the world with love. ${ }^{20}$ In this invitation given by the council to moral theology, there is an imaginary culmination of moral theological discourse of the first half of the 20th century, given mostly by an intense confrontation with personalistic philosophy and the newly discovered responsorial structure of biblical ethos. In this discourse, personal responsibility is about to be promoted as a central category. ${ }^{21} \mathrm{~A}$ substantial paradigm shift in moral theological discourse is well illustrated by the change or new preference in using the designation of this moral theological discipline. The term moral theology is being withdrawn and is replaced by the concept of theological ethics. While the term moral theology implies that first there is a requirement that needs to be fulfilled, and only then is it possible to speak about theology, that is to say, of the relation to God (which is justified by that fulfilment), the term theological ethics introduces the opposite. First, there is God's action for the benefit of man, God's demand for love. Man is being challenged to give a free answer, to be responsible. In other words, the first is not the morality but the gospel, the joyous proclamation of the redemption of man and his or her salvation, which does not exclude anyone from it. It is this gospel faith (or biblical ethos) that is the basis of the numerous statements and texts written by Pope Francis. Biblical, evangelical, theological ethics is not, as he says, stoic ethics. It is more than asceticism. It is not just a practical philosophy, nor a catalogue of sins and mistakes. The Gospel firstly invites us to respond to God, who loves and rescues us, by recognising Him in others, by coming out of ourselves and seeking the good for all. ${ }^{22}$

For theological ethics, it also means not concentrating primarily on human failure, not on a human's no but on God's yes, in the light of which it is possible to judge properly a human negative response. ${ }^{23}$

However, the presented character of theological ethics does not yet fully reflect the question of the importance of this ethics in the study of social work and its practice. This is so especially in situations where the impulses contained in theological ethics are conditioned by their Christian understanding, which is not a prerequisite for social work and its students. Is this generally not expected or required? In seeking answers to this question, it is necessary to go back to the abovementioned ideas of Joseph Ratzinger, adding them to the ideas he later formulated as Pope Benedict XVI, as well as to the ideas of the evangelical ethics of Wolfgang Huber.

Ratzinger, as we have shown above, reflects on the universality of Christian faith, respectively its moral vision, which, according to him, is nothing specifically Christian. On the contrary, as a synthesis of 'the great intuition of mankind', ${ }^{24}$ it represents the full development of reason and by its essence becomes a guardian of moral duty, which is the very content of the dignity and freedom of man. ${ }^{25}$ In other words, Ratzinger - later as Pope Benedict XVI - wants to point to

20 Cf. Optatam totius, Dekret o výchově ke kněžství, in Dokumenty 2. vatikánského koncilu, Praha: Zvon, 1995, article 16.

21 Cf. HILPERT, Zentrale Fragen christlicher Ethik. Für Schule und Erwachsenenbildung, Regensburg: Pustet, 2009, p. 17. However, it is also despair over the consequences of an 'obedient' responsibility which causes a fundamental transformation of the theological-ethical paradigm of this period. Perhaps this transformation of morally theological paradigm is represented the most clearly in the moral theology of Bernhard Häring (1912-1998) Based on his life experience from World War II, he states: 'However, I have experienced, unfortunately, even the most absurd obedience of Christians towards the criminal regime. And it has radically manifested itself in my thinking and acting in moral theology. After the war, I returned to moral theology with a firm commitment to teach it so that its core is not obedience, but willingness to accountability, courage to accountability. And I believe I have remained faithful to this determination, certainly not to the detriment of true obedience, namely responsible obedience, associated with freedom and critical thinking.' Bernhard HÄRING, Meine Erfahrung mit der Kirche (Anm. 6), 35, cited in HILPERT, Zentrale Fragen christlicher Ethik, p. 18.

22 FRANTIŠEK, Evangelii gaudium (hereinafter referred to as EG) Radost evangelia. Apoštolská exhortace o hlásání evangelia v současném světě. Praha: Paulínky, 2014, article 39.

23 Cf. Joseph kardinál RATZINGER, Obnova morální teologie: Perspektivy 2. Vatikánského koncilu a encykliky Veritatis splendor, Communio, 3/2006, p. 304.

24 Joseph kardinál RATZINGER, Naděje pro Evropu?, p. 24.

25 Cf. ibid., p. 23 . 
the profoundly inspiring potential of theological ethics that far exceeds the boundaries of the Church community, especially in its attitudes which are not distant from the general human experience, the reality of this world, and associated issues. Theological ethics brings into this general human experience a specific view that aims to purify, transform, differentiate, and heal this experience, respectively to raise it and bring it in the light of God's love in order to fulfil all that is truly human. ${ }^{26}$

The universal significance of theological ethics is also confirmed by the mentioned evangelical ethicist, Wolfgang Huber, when he recalls that for moral consensus in pluralistic society, it is of central importance whether universalist principles, most likely determining moral behaviour, are embedded in the beliefs and religious practices of different groups in society. ${ }^{27}$

And he adds that, in the case of differences of belief (which touch even the basic value orientation), one of the tasks of theological ethics is to place (in the pluralistic society) its own ethos in relation to other ethical attitudes. Part of the ethos of theological ethics is, as he rightly points out, the order of society as a whole. It includes respect for the dignity of all people and the guarantee of their rights.

Theological ethics specifically stay by 'those who are weaker, injured in their rights, those whose lives are threatened, regardless of their belonging to a community of believers or of their belief' ${ }^{28}$

It is precisely in the abovementioned characteristics of theological ethics where one can see the legitimacy of ethical studies in university education. Especially in the field of social work, provided that (as the abovementioned commission at Harvard University has stated) it is not a matter of instilling a particular religious view but to help understand the relationship between religious and secular institutions, thoughts, and forms of practice, and to learn more accurately to understand one's own beliefs and values. In other words, this study is about giving students a comprehensive view of the reality of life, respecting freedom of conscience and religion. This respect is also present in the offer that Joseph Ratzinger gave to the unbelieving world years ago - to try to live as if God were (veluti si Deus daretur). According to Pera, this is an offer of respect towards the 'lay' God, which is the conscience of a person. It makes him or her a morally active being..$^{29}$ To this offer Ratzinger was brought by the conviction that without God, respectively without Christianity and without the great intuition of mankind, everything loses support and measure, and that this situation leads man to the edge of the abyss, to his or her complete displacement, ${ }^{30}$ whereas 'availability to God makes us open towards brothers and sisters and to life as well, which is understood as a joyful mission in spirit of solidarity. ${ }^{31}$

However, these characteristics and delimitation of theological ethics do not sufficiently affect its continuous progressive shifts in the form and content of its paradigm and thus its full real sig-

26 Cf. RATZINGER, Obnova..., p. 307. Cf. also BENEDIKT XVI., Deus caritas est. Encyklika nejvy̌š́ího pontifika Benedikta XVI. Praha: Paulínky, 2006, article 3.

27 Wolfgang HUBER, Etika. Základní otázky života, Praha: Vyšehrad, 2016, p. 19.

28 Ibid., p. 19.

29 Pera believes that such a 'layman' God gives man the opportunity to realise his or her finality, poorness and importance. It is the God who is rebuking or praising man mysteriously. He is the God of man's anxieties and enlightenment. Cf. Marcello PERA, Návrh, který je treba prijmout, In Joseph RATZINGER, Evropa Benedikta $z$ Nurie v krizi kultur, Kostelní Vydř́: KNA, 2006, p. 19.

30 Cf. RATZINGER, Evropa Benedikta $z$ Nursie v krizi kultur..., pp. 38-43 (mainly p. 41.)

31 BENEDIKT XVI., Caritas in veritate (hereinafter referred to as CV) Láska v pravdě. Encyklika o integrálním lidském rozvoji v lásce a pravdě. Kostelní Vydř́i: KNA, 2009, article 78. 
nificance in the study of social work. Particularly in recent years, this progress seems to be quite powerful, if not a breakthrough. The issue of natural law, its significance and application, is newly reflected here.

While Pope Benedict XVI reiterates the need for respect for the natural law, which is a law inscribed in (human) nature', and as such 'it is a real guarantee offered to everyone - to live freely and to honour one's own dignity, ${ }^{32}$ it seems, at the same time, he forgets to take sufficiently into account the pitfalls and the possibilities of life which determine its fulfilment. The International Theological Commission, in a December 2008 issue on moral theology and ethics, removes this 'handicap' to a certain extent by specifying the essence, meaning and application of this law. It notes the importance of the moral dispositions of the person in charge (with respect to the final form ethically justifiable behaviour), and also specifies the requirement for theological ethics in a pluralistic society.

The document of the International Theological Commission, with regards to natural law, gives in some way 'new', important distinctions. Natural law cannot, as the document recalls, be viewed as 'a predetermined set of norms imposed on a moral entity a priori. A natural law is the source of objective inspiration in the process in which the moral entity arrives at his or her decision. ${ }^{33}$ With reference to Thomas Aquinas, the historicity of natural law is reflected here. It means that 'one cannot remain only on a general level when talking about the first principles of natural law', ${ }^{4}$ but it is equally necessary to also go into the concrete issues and thereby be even more confronted with the variability of application and the uncertainty. In this context, the document mentions that 'concrete application of natural law regulations may take different forms in different cultures or in different epochs within an identical culture. ${ }^{35}$ Thus, 'morality is concerned with contingent facts which change over time. ${ }^{36}$ In connection with the desired form of theological ethics and the outcome which this knowledge implies it is evident that 'clear syllogistic deduction is not an adequate means in morality. ${ }^{37}$ When considering specific situations, it is important to choose wisdom which builds on experience. ${ }^{38}$

The fundamental testimony when talking about theological ethics is that it 'cannot be restricted only to the act of pronouncing the norms, ${ }^{39}$ but it must also support the formation of a subject so that in a particular situation one is able to apply universal commands of natural law to specific conditions of existence in different cultural contexts. In particular, it is the cultivation of a prudentia virtue which takes into account the particularities when assessing concrete actions without seeking a cheap compromise with regard to moral values. In other words, a wise man must have knowledge not only of a universal one but also of a particular one, and on the basis of Thomas

32 Ibid., p. 23.

33 Dokumenty Mezinárodní teologické komise věnované morální teologii a etice (hereinafter referred to as MTK). Initial study by C. V. POSPÍŠIL, Kostelní Vydří: KNA, 2010, article 59.

34 MTK (International Theological Commission), article 53. According to Thomas Aquinas, 'practical reason deals with random matters, among which there are human deeds, and therefore, although on the general level there is a certain need, the more one descends to his or her own affairs, the more one finds some faultness [...]. In deeds, however, there is not the same practical truth or correctness in all human deeds when one speaks about their own ones. On the other hand, one finds it when dealing with the general ones. And those, who are equally correct in their own affairs do not have the same knowledge about it [...]. The more one descends to individualities, the more insufficiency he or she can find.' Thomas AQUINAS, Summa theologiae, Ia-IIae, q. 94, a 4.

35 MTK, article 53. The document explicitly mentions changes in attitudes within the Christian tradition to slavery, loans and interest, fights, or death. Cf. ibid.

36 MTK, article 53.

37 MTK, article 54

38 Cf. MTK, article 54. The above-mentioned requirement can be seen in the above-mentioned general transformation of theology, which is based on a departure from the purely deductive method toward an inductive approach.

39 MTK, article 56. 
Aquinas's belief (to which the document refers), it is necessary to prioritise the knowledge of the particular facts closely related to that act. ${ }^{40}$

The ethical approaches and arguments contained in the International Theological Commission document (links to Thomas Aquinas) are inherent in the widely discussed apostolic exhortation written by Pope Francis Amoris laetitia (2016). The Pope not only adopts these ethical approaches but (considering the pastoral character of the document presented by him), he further elaborates and specifies them with regard to pastoral practice, thus he completes the form and significance of theological ethics on its gospel basis (which was again accented by the Second Vatican Council). It allows us to better understand here the previously reflected meaning of ethics for the field of social work practice. This is a series of principles and methodical suggestions. It is primarily an emphasis on personal responsible freedom and respect for the dignity of a person, which excludes a practice based on the strict application of the ethical norm, the law, hiding behind set criteria and standards in social work without proper consideration of a particular client's life story, his or her current dispositions, growth limits, personal responsibility, and so on. Indirectly, there is a demand for the realisation of a committed personal interaction between the social worker and the client, which is to be determined by the logic of sympathy by the assisting worker. This logic excludes overly hard and rash trials and the final conviction of people in need. On the contrary, it respects the process of maturity in every person and is characterised by time availability, perseverance and patience, respect for the client's conscience, etc. ${ }^{41}$

\section{Conclusion}

In conclusion, it is possible to offer a brief answer to the question solved here about the importance of theology, especially theological ethics within the university study of social work and, consequently, its practice, and respectively its justification.

Ethics, as outlined above, is one of the central sciences for social work. It plays an important role here. Whether it becomes important in the practice of social work itself, however, depends to a large extent on how ethics is understood. When studying ethics in social work, it is not possible to learn only knowledge or a list of facts, the mere knowledge of the ethical code, ethical theories, ethical dilemmas and coping methods, the enumeration of human rights, or the adherence to not always essential details of ethical discourse, and to partial knowledge. The emphasis is primarily on capturing and understanding the contexts of ethical approaches and their importance in relation to the practice of social work in its problems, challenges, and perspectives, including the reflection of issues related to the personal responsibility of the interested parties, that is, social workers and clients, respectively the importance of individual ethical motivations in the context of socially ethical relations of the helping organisation (its settings and functioning), or in the context of society.

It seems that the study of theology, respectively of theological ethics, as part of social work can be considered as justified by the above. Its significance does not seem to be merely of an occasional nature. This study, or study of theology, provides a complex, universal view of man and the reality of life. It creates the necessary prerequisite for perceiving the contexts of the individual stories and relationships that human life and specific areas of human practice involve while reflecting

40 Cf. MTK, articles 56, 58. Cf. also Thomas AQUINAS, Sententia libri Ethicorum, Lib. VI, 6 (ed. Leonina, t. XLVII, 353-354).

41 Cf. FRANTIŠEK, Amoris laetitia. Radost z lásky (hereinafter referred AL). Posynodální apoštolská exhortace o lásce v rodině. Praha: Paulínky, 2016, especially chapters 6 and 8. 
transcendent horizons. It reflects what is humanly decisive in the area of social work. Not only is it limited to the relevant knowledge of ethics, it is aimed at encouraging the personal responsibility of social workers and clients, their individual ethical motivation, etc. Theological ethics, in its latest form, emphasises the personal responsibility of a person, and his or her ability to ethically distinguish and decide in the context of his or her complex, often complicated reality. It points out the importance of virtues, especially the virtues of wisdom and providence. It is precisely in this emphasis (with its value content) where (in our opinion) it is possible to see the essential importance of studying ethics in social work, which also determines the quality of social work practice, in which human dignity, human rights, freedom, solidarity or social justice are valuable. These are generally defined basic value frameworks for it.

\section{Contact}

Assoc. Prof. Jindřich Šrajer, Dr. theol.

University of South Bohemia in České Budějovice

Faculty of Theology, Department of Ethics, Psychology and Charity Work

Kněžská 8, 37001 České Budějovice

srajer@tf.jcu.cz 